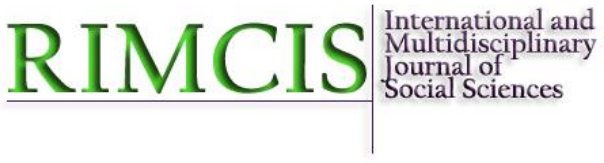

\section{Hipatia Press}

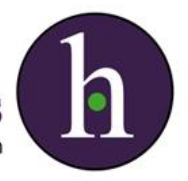

Instructions for authors, subscriptions and further details:

\title{
The Debate of Minimizing Subjectivity in Gender Studies: A Critical Analysis
}

Madiha Nadeem ${ }^{1}$

1) Lahore College for Women University, Pakistan

Date of publication: July $30^{\text {th }}, 2019$

Edition period: July 2019 - November 2019

To cite this article: Nadeem, M. (2019). The Debate of Minimizing Subjectivity in Gender Studies: A Critical Analysis. International and Multidisciplinary Journal of Social Sciences, 8(2), 164-187. doi:

10.17583/rimcis.2019.4134

To link this article: http://doi.org/10.17583/rimcis.2019.4134

\section{PLEASE SCROLL DOWN FOR ARTICLE}

The terms and conditions of use are related to the Open Journal System and to Creative Commons Attribution License (CC-BY). 


\section{The Debate of Minimizing Subjectivity in Gender Studies: A Critical Analysis}

Madiha Nadeem

Lahore College for Women

University

\section{Abstract}

The social sciences have always been contested on the philosophical and ethical grounds of producing scientific knowledge. Similarly, the standpoints of Gender studies are analytically linked to certain domains of reasoning for human behavior. It discusses social phenomena from a societal and cultural perspective, which raises questions for the scholars of this subject about the application of particular procedures for understanding realities guided by some ideologies (Söderlund \& Madison, 2017). This article critically evaluates the theoretical debate on ways of upholding the objectivity in this discipline by minimizing the role of subjectivity in the construction of new knowledge. It is concluded that by adopting techniques such as bracketing, triangulation, reflexivity and various other theoretical stands mentioned by scholars, feminists, and social scientists, the struggle of producing objective systematic knowledge can be promoted in gender studies and other social sciences.

Keywords: gender studies, objectivity, epistemology, subjectivity 


\section{El Debate sobre Minimizar la Subjetividad en los Estudios de Género: Un Análisis Crítico}

Madiha Nadeem

Lahore College for Women

University

\section{Resumen}

Las ciencias sociales siempre han sido cuestionadas desde fundamentos filosóficos y éticos como productoras de conocimiento científico. De manera similar, los puntos de vista de los Estudios de Género están vinculados analíticamente a ciertos dominios de razonamiento sobre el comportamiento humano. Se debaten los fenómenos sociales desde una perspectiva cultural y societal, lo que plantea preguntas a los académicos de esta materia sobre la aplicación de procedimientos particulares para la comprensión de realidades guiadas por algunas ideologías (Söderlund y Madison, 2017). Este artículo evalúa críticamente el debate teórico sobre formas de defender la objetividad en esta disciplina por la minimización del papel de la subjetividad en la construcción de nuevo conocimiento. Se concluye que los esfuerzos por producir conocimiento objetivo de una forma sistemática puede ser promovido en los estudios de género y otras ciencias sociales con técnicas tales como el horquillado, la triangulación, la reflexividad, así como por varios otros soportes teóricos mencionados por académicos, feministas y científicos sociales.

Palabras clave: estudios de género, objetividad, epistemología, subjetividad 


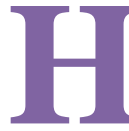

aving a certain ideology in any subject, especially social sciences can impede the systematic way of producing scientific knowledge, create bias during interpretation, which perhaps leads to getting desired answers (Carl, 2015; Klein \& Stern, 2009). In this regard, academia has been suspicious towards Gender studies with assertion of having biases (Baumeister, 2015) in its ideology, having theories and methods (Söderlund \& Madison, 2017; Strom, 2007), with political agenda and is not scholarly adequate (Rothstein, 2012; Sokal, 2006; Zalewski, 2003).

Debates about this discipline revolve around objectivity and subjectivity bias, different epistemological and philosophical standpoints, impartiality of science, and having an activist plan (Brown, 1997). This field claims to be dominated by the theories and movements of feminists (Anderson, 2015; Curthoys, 2014; Liinason \& Holm, 2006) with influences from relativism claimed by Friedman's 1997 (as cited in Söderlund \& Madison, 2017), critical theory (Bergman, 2000; Thurén, 2002) and postmodernism (Brodribb, 1993). Moreover, feminists are more concerned about exploring the ways this discipline can bring desirable societal changes (Thurén, 2003). This seems to be contradictory to the principles of other scholarly traditions, for instance disinterest (Merton, 1973). Similarly, supporters of interpretive, critical, and postmodern theories do not accept the objective knowledge rather they promote subjectivity. They claim that facts and realities are socially constructed and politically settled. Furthermore, they argue that objectivity is a tool of the dominant discourse, whereas, science itself is a part of politics (O’Meara, 2001).

While producing scientific knowledge, it is recommended to uphold a critical perspective toward some of the notions proposed in the social sciences such as, the assumption that the researcher must maintain neutrality and distance from the social realities being studied, which is contested by the feminists. A feminist approach consequently, deals with the methodological process, the issues of objectivity and issue of the relationship between the researcher and the subject. According to feminists, definitions of reality cannot be imposed on subjects, as it is contradictory to the aims of feminist work towards women (Acker, Barry \& Esseveld, 1983). 
In this context, thus it is important to understand the stance of feminists regarding research philosophies and objectivity. Basic principles of feminist research as highlighted by Acker et al. (1983) are: contributing to women's emancipation through knowledge production that can be used by women themselves; applying non-oppressive method of producing knowledge, challenging dominant scholarly academe by developing feminist critical perspective.

Feminist scholars highlighted the absence of women's interests, experiences and voices in the sciences while criticizing the approaches used by the Positivist and other traditional methods of science (Smith, 1977). According to feminists, their methods of science are male dominated and use universal experiences of men or relatively privileged women to understand women's experiences (Stanley \& Wise, 1993; Sherman \& Beck, 1979). They also pointed out the science is used to control women through medicine, psychiatry, or through scientific theories of the family, work and sexuality (Millman \& Kanter, 1975). Additionally, feminists see quantitative method as a means to reproduce and nurture male hegemony and patriarchal social structures and relation by incorporating the views of the dominant group (Oakley, 1998a; Risman, 1993).

Similarly, feminist researchers also criticize other principles of positivism, such as distance between researcher and subject, separation of knower and known for research validity (Cook \& Fonow, 1986; MacKinnon, 1982) value-free way of inquiry, data collection through fixed responses and analysis by using statistics (Oakley, 1998b; Risman, 1993). Stacey (1988) discussed that imbalance of power between researcher and subjects permit the researcher to control the research process and results.

Debates of feminists on the intersection of gender with sexuality, race and class highlighted different aspects of power imbalances such as, black feminist Patricia Hill and others from underrepresented groups, have intensely criticized the existence of partialities in the academic work of white feminists. They argued that contemporary research methods are subjective because they produce distorted social reality. Moreover, they claim that the knowledge produced by using the conventional scientific framework, has been dominated by white, middle class, heterosexual men, and same pattern can be followed in some feminist writings produced by 
white, middle class, heterosexual women. Therefore, the claim of objectivity and neutrality are hidden under the masculine racial norms (Metso \& Le Feuvre, 2006).

They refer "scientific objectivity" as "male subjectivity" (Caplan, 1988). Similarly, other researchers highlight the risks of biases in traditional quantitative research methods from selection of subjects to other different stages of the research (Smith \& Noble, 2014). However, some feminists reasoned that criteria of quantification process in the selection and analysis of data decreases the chances of producing subjective knowledge (Sprague \& Zimmerman, 1989). Therefore, the conclusion of all criticism on quantitative method leads to debate on objectivity and qualitative method from the perspective of feminist academicians. Various researchers provided arguments in support of qualitative method when it comes to include women's voices, for instance, Cook \& Fonow (1986) argued that qualitative research technique makes the subjects and researcher attached, while Westcott (1990) stated researchers' analytical frameworks on their subjects can be avoided in qualitative research which let women respondents' voices to be included. On the contrary, some feminist researchers have discussed the reservation regarding maintaining objectivity while selecting and interpreting data in qualitative researches, there is an ample chance of imposition of researcher's own values in the research process (Sprague \& Zimmerman, 1989). As indicated by Ryff (1895), that unstructured interviews are more likely to present the researcher's bias and notion, especially in case of students if not trained (Richardson, 1996). Consequently, validity and bias remain problems for researchers in the social sciences and humanities, regardless of their methodological selection (Metso \& Le Feuvre, 2006).

The work of Sandra Harding regarding gaining objectivity in feminist research is highlighted by Wylie (2004), who asserts that standpoint theory could increase the objectivity in research. Standpoint theories are based on two fundamental principles: knowledge is socially constructed and shaped by individual experiences and location embedded in hierarchically structured systems of power relations (Wylie, 2004). Moreover, the socially situated knowledge leads to have epistemic privilege based on some subjects of inquiry related to that social location (Hicks, 2011). Consequently, feminist 
standpoint theory claims that feminists must be given greater epistemic privileges than other social groups (Hicks, 2011).

Similarly Harding (1993) argued that the political and scientific significance of "situated knowledges" (Haraway, 1988) proposed the idea of gaining strong objectivity from the perspective of the "marginalized lives". She further said that although knowledge produced by Western authors claimed as value-free, context-independent, but it is always embodied and historically located, so according to her, taking the perspectives of deprived groups can scientifically reduce the chances of influencing the hidden contextual beliefs about knowledge, which consequently may increase the objectivity (Harding, 1993).

Tannoch-Bland (1997) revealed the lives of marginalized as a source of objectivity-maximizing questions; similarly, Harding (1993) considered "social situated knowledge" as a systematic scientific research. Therefore, social scientists can use Harding's idea as a tool for scientists to think from the perspective of others, especially marginalized to explore the hidden biases in researches.

Furthermore, Harding (1993, p.136) introduced the process of systematic reflexivity by asserting, "the subject of knowledge can be placed on the same critical, causal plane as the objects of knowledge". Once scientists "achieve" and use other standpoints to reveal the communal bias and distortion in their existing knowledge, they become both the subject and object of knowledge "from the perspective of the scientific method". Harding asserts a "causal symmetry" whereby the "same kinds of social forces that shape objects of knowledge also shape knowers and their scientific projects" (Harding, 1993, p.64). According to her, the concept of objectivity is "useful in providing a way to think about the gap that should exist between how any individual or group wants the world to be and how in fact it is" (Harding, 1993, p. 72).

Gender studies as a discipline has its heritage from social sciences, so it is imperative to understand the debate of objectivity in social sciences. The requirement of objectivity in social science and the elimination of ethnocentric biases in researches have been highlighted by many social thinkers such as Durkheim, Max Weber and Radcliff Brown. Likewise, Malinowski supports the use of cultural relativism in anthropological studies 
in order to guarantee objectivity. However, maintaining objectivity in the research process always remains debatable. Gunnar Myrdal claims that complete objectivity is a fantasy, which can never be reached. Since the studies in social sciences are guided by some theoretical views, which can lead to subjectivity (Sociology Guide, 2018). Similarly, Merton argues that the selection of the subject of study is also linked with ideological and personal biases of the researcher (Merton, 1973).

\section{Debates on Objectivity in Social Sciences}

The concept of objectivity has always been debated in research method used in social sciences. Epistemological models, which come under social science, fall in the category of the realist or the models of an idealist (Smith, 1983; Smith \& Heshusius, 1986). The assumptions of the realist model are that reality exists independently and that a researcher must exterminate all bias and presumptions, must be emotionally detached from the research process and must use a value-free, neutral language. Tools used in this model to ensure objectivity are; reliability, internal validity, and external validity, whereas this model applies randomization, fixed tests, hypothesis testing and the separation of the researcher from the subject to reduce bias. Other models which do not follow such rules can be declared as subjective due to imposition of the values, emotions, or the interests of the researcher (Cooke, 1994).

On the other hand, the idealist model as cited by Cooke (1994) argued that the researcher could not be separated from the subject. Irrespective of exercises used to reduce subjectivity, the researcher in this model, select theories, methods and interpretations of data. In this model, to understand the meaning that others give to their situation is dependent on researcher's own capacity and skill for understanding. Since the subject is the one who can verify or revise a researcher's understanding of the subject, the independence of the subject and the researcher from pressure is a key to the process of understanding.

The realists understand the reality independently and objectively by applying practices to reduce biases whereas the idealists understand reality by giving equal status to the interpretations of the respondents being studied, 
the researcher, other researchers, and the reader. According to Cooke (1994) Foucault describes both models as complicated by stating that the objective nature of reality and the sense giving to the subjects are both constructed in particular power related historical context. Alcoff (2001) adds that Foucault considers all knowledge as political. Foucault's (1979) writing on discipline in the prison discloses the impartial and objective relation supposed by the realist stands on tools such as hierarchical observation, the panoptican, and the examination, which are not neutral.

Foucault seems reluctant to favor any model of reality as truth. He also criticized the totalitarian theories and the belief of realist model about one universal reality that can be discovered through the laws of association or causation (Foucault, 1980). Although these theories have provided useful tools for research globally, this concept of universal theories, unintentionally, compels local practices into a common mold, which is problematic.

Foucault rejected social scientists' assertion to objectivity by revealing the ways of mixing ethical and legal norms into scientific truth. For instance, he examined that crime was evaluated against a normal standard set by the scientific knowledge, whereas punishment considered lawful under the legal system. Amery (2008) while analyzing the work of Foucault explains that any deviation from the law treated as violation of objectively known human nature. Moreover, Foucault used historical philosophies about madness and sexuality to challenge the historical notions of reality and belief about ethics and laws (Amery, 2008).

Similarly, doing research in social science depends on the logic that reality can be divided into commonly selected categories based as a vital part of the phenomena under discussion which might be done by using tools such as ideal forms (Weber, 1978), categories (Charmaz, 1988), or definitions (Babbie, 1986). Foucault (1991b) does not agree with such division and process of reduction, because such categories are made by the researcher in order to decrease possible significant variations into commonalities. Such reductions further become decisions, which limit the area of consideration of the researcher. Ultimately, definitions, categories, and logic are all parts of practices whose power can be recognized by relating them to other components of practices. In case of necessary reduction, Foucault (1991a, 
1991b) urges to classify the practices into their elements. While reaching to saturation during this process of breaking down elements where elements can be seen as finite, so it cannot be presumed that this process is completed. As researchers do it, so categorization of some reality cannot be claimed.

Foucault's $(1980,1984)$ study of truth also uncovers the criticism of the realist model. According to him the truth is “... a system of ordering procedures for the production, regulation, distribution, circulation, and operation of statements" (Foucault, 1980, p.133). So procedures for producing truth have a power of ruling, which statements are acceptable or unacceptable (Foucault, 1984). Thus, Keeley (1990) indicates that Foucault persuades a researcher to implement an approach of contestability, to employ analytic devices, and to discover the possibilities.

Similarly, Foucault provides some other strategies to explore reality. Foucault (1984) focuses on specific examples with historical studies in order to understand the existing structures and its background. By doing this, Foucault plans to reject the pursuit for formal structures with universal value. Additionally, Foucault (1980) proposes to ponder on practices by rejecting the analysis at the level of deliberate decisions. He (Foucault, 1980) also encourages researchers to analyze power at the indigenous level and explore how local practices are financed, occupied and used by other practices. By highlighting these techniques, Foucault rejects centralized methods of understanding the phenomena (Cooke, 1994). Similarly, Foucault's way of studying practices is considered as tools, devices or method (Foucault, 1980). So practices can be explored as discourses, institutions, architectural forms, regulatory decisions, law, administrative measures, scientific statements, moral propositions, etc. (Foucault, 1980).

Another method used by Foucault to examine the way practices work is to concentrate on discourse with the notion of the episteme (Foucault, 1972; 1980). The episteme is a device used to understand the truth. Therefore, to study which discursive and non-discursive elements are related and the way to separate true statements from those not considered to be true, Foucault (1984) specifies three areas of practice systems: relations of control over things, relations of actions upon others, and relations with oneself. For instance, forming moral agents of own actions, Foucault (1984, 1988a, 
1988b, 1990a, 1990b) starts by looking at what part of the self or action is taken as ethical feature.

He then explores forms of subjugation by which people are encouraged or driven to identify ethical responsibilities and method by which people can become the ethical subject. He then reveals how social science could appear from the application of discipline to a limited population but could not develop with the use of punishment on the body of the convicted by the monarch (Cooke, 1994). Thus, Foucault's critical approach is applied to study how one method replaces others. This approach seems similar to the grounded theory (Charmaz, 1988) and the participatory action approach.

Foucault's method not only gives an understanding of social practices but also provides tools for social criticism. The approach of social criticism for both the realists and the idealists linked with the separation of fact and value. For realists, fact and value are separate and reality is value free, whereas according to idealists fact and value in the act of knowing cannot be separated. By using the tool of the genealogy, Foucault links the fact and value through understandings of the term power (Cooke, 1994). He simply analyzes how activity is controlled through the systems of regulations, bodies and actions. He explains the tools by which power is exercised on people: tools than rank and judge people (Foucault, 1979). Dreyfus and Rabinow (1982) also state for Foucault, rules function as descriptive regularities and as a prescriptive operative force.

Research method is also a device, which controls the findings and the discourses. In this regard, Foucault encourages the social researchers to study social practices at the point when made as problematic without having preconceived notion. This does not indicate that using the method prevents the regulating discovery and discourse. It simply means that the researcher cannot have preconceived notions of what practices exist and how they are being made problematic before exploring it (Cooke, 1994). Therefore, Foucault's method provides a systematic tool to analyze and conduct studies.

The work of Foucault has become an important tool for social science researchers to apply his work to understand the power structures and relation (Hook, 2001; Nicholls, 2009; Fadyl et al., 2013). Several feminists in this regard explained the different aspects of women's oppression by using the work of Foucault, especially his theory of power and its connection to the 
body. Foucault's notion that sexuality is the outcome of specific power relations and it is not something considered as natural offered feminists a critical framework to analyze the way women's identities and experiences are deprived and regulated within certain culturally governed concepts of feminine sexuality (McNay, 1991). Feminists also used his concept of sexuality to understand the dominant pattern of identities and sexualities. It facilitates the feminists to contest the concept of fixed identities and uncover the diverse sources of women's subordination (Deveaux, 1996).

Similarly, the institution of marriage is also analyzed by using Foucault's theoretical notions of power relations "power is exercised only over free subjects, and only insofar as they are free" (Foucault, 1982, p.221). The relation of power is evident in gender relation in the form of violence (Jaramillo Ruíz, 2013). Marriage, as a type of gender relation, serves as an example for evidencing the similarities. It is one of these complex strategic relations that characterize one type of gender relations; and not merely an institution "to ensure men's power through their access to women's bodies" (Boucher, 2012). Moreover, feminists also use the concept of the docile body given by Foucault to explain the expression of the subjugation of women. Additionally, they used the surveillance paradigm as women's collusion to set standards of femininity by patriarchy (Deveaux, 1994).

Bordo (1993) states that effect of power on body highlighted by Foucault's description in Discipline and Punish is linked to the practices of women to embrace femininity. Additionally, cultural norms and attitude adds to the internalized power to further suppress women (Sawicki, 1996). Women meet the dominant standards of femininity through dieting, exercise, fashion, beauty techniques, which nurture the desired women's bodies. Moreover, Haber (1996) adds that the socialization process dictates women to evaluate themselves from the perspective of dominant male gaze. In this way, the Foucault's concept of power identifies the multiple sources of women's subordination.

Various other researchers discussed many ways of gaining objectivity in the social sciences. For instance, Mannheim emphasized that objectivity can be attained in the social sciences, but not entailing to eradicate value judgements from the process of recognizing social phenomena. Despite using fixed criteria to comprehend and evaluate the human actions, social 
scientists can apply the concept of "relationism" given by Karl Mannheim while maintaining their positions as objective (Shmueli, 1979).

According to Mannheim, this notion "relationism" guided against deception in the research process. It also challenges the claim of a time based truth in social sciences as legitimate "independently of the values and positions of the subjects and unrelated to the social context". This method gives the researcher clear sight about the innate virtues related to action. The main idea of this concept is openness to the opinion of others, which leads to study the reality without misconception. This concept achieves more than an epistemological role and accepts the historical accounts and rituals through critical debate. Moreover, this concept seems similar to Popper's assertion that the "objectivity of science resides in its being a social enterprise" (Shumeli, 1979).

Longino (1990) asserts that scientific objectivity is social and procedural. It counts as social because of its interaction with the social scientists, it is also considered as procedural due to following special techniques of producing scientific knowledge, and she concentrates more on empirical sufficiency (Hicks, 2011).

She highlights four critical standards in order to ensure that gained knowledge is scientific and objective (Longino, 1990). She asserts that this process is required to reduce the subjectivity related to personal beliefs, feelings, desires one wishes for and political principles. On the other hand, Longino (1990) stresses several times that ethico-political principles have a valid, and a critical role in determining the epistemic criteria. The four principles mentioned by her are: identification of possibilities for criticism, common principles, reaction of a group and parity of intellectual experts (Hicks, 2011). Longino (1990, p. 80) suggests

When background assumptions are shared by all members of a community, they acquire an invisibility that renders them unavailable for criticism. They do not become visible until individuals who do not share the community's assumptions can provide alternative explanations of the phenomena without those assumptions. 
Such individuals might include members of an oppressed racial, ethnic, religious, sexual, or economic group, or simply those who offer radical alternative theories. To block this possibility, Longino requires an "equality of intellectual authority", which "disqualifies a community in which a set of assumptions dominates by virtue of the political power of its adherents" (Longino, 1990). She explains this condition as "tempered equality". The social or financial status of an individual or group in a society cannot decide about which views of others can be taken utterly (Longino, 2002).

By claiming this, shared belief of all members of society are not available, she uses this criteria as the base of criticism of the omission of women and other minorities from science (Longino, 2002). She argues, if these groups are not included in producing scientific knowledge than the existence of prejudice belief will remain present in the members of the community and hence these beliefs cannot be critically evaluated, thus it violates the criteria of objectivity. Therefore, the voice of marginalized groups must be incorporated. She states, "a community must also take active steps to ensure that alternative points of view are developed enough to provide a source of criticism and new perspectives" (Longino, 2002, p. 132).

Longino's criteria of objectivity can be achieved by including historically deprived communities and making them formally equal with historically advantaged groups (Hicks, 2011). Likewise, Nazi theorists' work is also based on two major arguments: they consider the individual's location and participation in the political effort of gaining power as epistemologically important, and their position because of political struggle provides them epistemic privilege over others. So, Nazi academician asserts for this epistemically privilege. Consequently, they can take part in the society regulated as per objectivity criteria given by Longino if following the conducts that are profoundly contrary to their basic ethico-political beliefs (Hicks, 2011).

Newell (1986) also talked about ontological and procedural objectivity. Ontological objective refers to, see things with its actual features, the way they are without any ideology, to experience and to know things in their ontological state. Similarly, procedural objectivity is attained by using a method that reduces the chances of subjectivity or personal judgment. Examples of procedural objectivity are methods using already established 
tests. The score on tests does not need to be interpreted by using personal judgements. Operational definitions of concepts are another example of procedural objectivity. In social sciences, concepts are defined in order to make it measurable by using some standard procedures, which others can also employ. Additionally, it is assumed that used procedures will yield the identical findings as long as the standard rules are followed and the measured phenomenon does not change (Eisner, 1992).

Triangulation is another tool emphasized by researchers that can be used to increase the validity of a study by combining the data collection sources, which consequently reduce the chance of misinterpretation (Flick, 1998; Stake, 2000). The concept of triangulation is considered a way of enriching the study in postmodernism (Flick, 1998). Richardson (2000) used the term crystallization as a substitute for triangulation, as it accentuates the variety of angles in study.

Similarly, Shenton (2004) emphasized that a study's findings must indicate the experiences and responses of the respondents, in spite of the researcher's inclinations. In this regard, to increase the confirmability and decrease the bias, the function of triangulation is highlighted. Miles and Huberman (1994) assert that confirmability comes when the researcher acknowledges his or her own bias towards subjects and approach selection. Likewise, Bracketing is another tool highlighted by Tufford and Newman (2012) that can be used in social sciences to lessen the possible effects of emotions and subjectivity that may contaminate the research process and increase objectivity. It is a procedure of creating a distance from previous framework and suppositions to study the social reality without any bias (Bertelsen, 2005). According to Cutcliffe (2003), bracketing assists the researcher gaining deeper levels of reflection across all stages of the research process from selecting a topic and population, designing the interview, collecting and interpreting data to report findings. The reflection process can facilitate in reaching more deep analysis and results. One of the methods used in the process of bracketing is scripting memos throughout data collection and analysis. These memos can be used to inspect and reflect upon the researcher's involvement with the data.

Furthermore, by highlighting the forms of Memos, Cutcliffe (2003) states that the theoretical form of notes clarifies the cognitive process, whereas, 
methodological notes explains the procedural parts of research, and observational notes can facilitate the researcher to examine the emotions about the study. Glaser (1998) illustrates that the notes taking practice can provide insight to researcher about accepting the presumptions. Rolls and Relf (2006) identified taking interviews with an outsider as another tool used to expose subjectivity. These interviews held in non-hierarchical and empathetic manners, which works as a border between subject and researcher. This procedure sometimes becomes official by involving monetary means, scheduling interview time, agreement of confidentiality and sharing of research report. Bracketing interviews at different stages of data collection reveals themes that may reduce the emotional feeling in researchers, which may restrict him/her to go further for exploration. This technique facilitates the researcher's ability to understand the respondents' experiences and phenomenon deeply with more clarity (Rolls \& Relf, 2006).

Nahrin (2015) emphasized that providing confidentiality and secrecy to the respondents can increase the chances of gaining authentic information for producing objective knowledge. For eliminating the risk of contamination of data taken from respondents, tokens of thanks could be given to them. Collection of data from multiple sources is also recommended to avoid the risk of modification of information or behavior while taking consent. Other techniques emphasized by Nahrin (2015) are pilot testing of interview questions, participant observation, and getting reviews from other researchers in order to produce value free knowledge.

Ahern (1999) indicates "reflexive journal" another technique of bracketing which starts in the beginning even before designing the research question. This stance highlights the preconceived notion about the subject throughout the research process. Different facets of reflexive journal are reasons for conducting a study, researcher's belief about different categories like race, gender, ethnicity, sexual orientation, social and political position, researcher's power in the study, value judgements (Hanson, 1994) conflict of interest with subjects, emotion towards participants and assumptions (Paterson \& Groening, 1996) and the researcher's decision to report as the first or third person (Porter, 1993).

Berger (2011) emphasized on the need of upholding objectivity in the research process by linking it with professional and academic ethics. 
Moreover, the objectivity unlocks the doors of reliable and systematic knowledge. Consequently, authentic knowledge can provide a base for the welfare of people. Berger (2011) also stated that objectivity enables the researcher to apply different frameworks to understand the reality, which can provide theoretical bases for future studies to create new insights.

It is concluded, under the light of the above discussion that social sciences researches always remain at the risk of subjectivity due to personal beliefs, background literature, values and feelings, however, it does not indicate that the constructed study is not completely reliable and generalizable. There are still tools and techniques to uphold objectivity and mitigate the influence of subjective bias as discussed above. It is also emphasized that researchers need to be sensitized about their personal or political belief during all stages of the research process from topic selection to report findings because it can influence the whole process so if it is difficult to avoid, then must be reported. Furthermore, it is also highlighted that empirical research through objective manners can not only contribute to the existing body of knowledge, but it can also provide a base for social policy implication which is a goal advocated by feminists.

\section{References}

Acker, J., Barry, K., \& Esseveld, J. (1983). Objectivity and truth: Problems in doing feminist research. Women's Studies International Forum, 6(4), 423-435. doi: 10.1016/0277-5395(83)90035-3

Ahern, K. J. (1999). Pearls, Pith, and Provocation: Ten Tips for Reflexive

Bracketing, Qualitative Health Research, 9(3), 407-11. doi:

10.1177/104973239900900309

Alcoff, L. (2001). Objectivity and its Politics. New Literary History, 32(4),

835-848. doi: 10.1353/nlh.2001.0050

Amery, F. (2008). Allowing the Other to Speak: The Relevance of

Postmodernism to Political analysis. Reinvention: A Journal of

Undergraduate Research, 1(2).

Anderson, E. (2015). Feminist epistemology and philosophy of science.

Stanford encyclopedia of philosophy. Stanford, CA: The Metaphysics

Research Lab. 
Babbie, E. R. (1986). The Practice of Social Research. 4th ed. Belmont, CA: Wadsworth.

Baumeister, R.F. (2015). Recognizing and coping with our own prejudices:

Fighting liberal bias without conservative input. Behavioral and Brain

Sciences, 38(e132). doi: 10.1017/S0140525X14001423

Bergman, S. (2000). A bird's eye on women's studies in the Nordic

countries. In S. Bergman (Ed.), Satsningar och samarbete: Nordisk

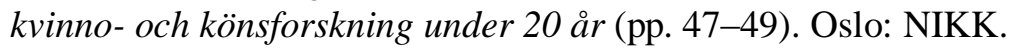

Berger, P.L. (2011). Invitation to sociology: A humanistic perspective. Open Road Media.

Bertelsen, P. (2005). Free will, consciousness and self: Anthropological perspectives on psychology. Berghahn Books.

Bernard, J. (1973). My four revolutions: an auto-biographical history of the ASA. In J. Huber (Ed.), Changing Women in a Changing Society. Chicago: University of Chicago Press.

Bordo, S. (1993). Feminism, Foucault and the Politics of the Body. In C. Ramazanoglu (Ed.), Up Against Foucault: Explorations of Some Tensions between Foucault and Feminism. London: Routledge.

Boucher, J. (2012). Male Power and Contract Theory: Hobbes and Locke in

Carole Pateman's The Sexual Contract. Canadian Journal of Political Science, 36(1), 23-38. doi: 10.1017/S0008423903778524

Brodribb, S. (1993). Nothing mat(t)ers: A feminist critique of postmodernism. Melbourne: Spinifex.

Brown, W. (1997). The impossibility of women's studies. Differences: A Journal of Feminist Cultural Studies, 9(3), 79-101.

Carl, N. (2015). Can intelligence explain the overrepresentation of liberals and leftists in American academia? Intelligence, 53, 181-193. doi: 10.1016/j.intell.2015.10.008

Caplan, P. (1988). Engendering knowledge: The politics of ethnography. Anthropology Today, 4(5), 8-17. doi: 10.2307/3032749

Charmaz, K. (1988). The Grounded Theory Method: An Explication and Interpretation. In R. M. Emerson (Ed.), Contemporary Field Research: A Collection of Readings (pp. 109-126). Prospect Heights, IL: Waveland. 
Cook, J.A., \& Fonow, M.M. (1986). Knowledge and women's interests: Issues of epistemology and methodology in feminist sociological research. Sociological Inquiry, 56(1), 2-29. doi: 10.1111/j.1475682X.1986.tb00073.x

Cooke, M. L. (1994). Method as ruse: Foucault and research method. MidAmerican review of sociology, 18(1\&2), 47-65. doi:

10.17161/STR.1808.5106

Curthoys, A. (2014). Gender in the social sciences. Australian Feminist Studies, 29(80), 115-120. doi: 10.1080/08164649.2014.930553 Cutcliffe, J. (2003). Reconsidering Reflexivity: Introducing the Case for Intellectual Entrepreneurship. Qualitative Health Research ,13(1), 136-48. doi: 10.1177/1049732302239416

Deveaux, M. (1996). Feminism and Empowerment: A Critical Reading of Foucault. In S. Hekman (Ed.), Feminist Interpretation of Michel Foucault (pp. 211-238). Pennsylvania: The Pennsylvania State University Press.

Deveaux, M. (1994). Feminism and empowerment: A critical reading of Foucault. Feminist studies, 20(2), 223-247. doi: 10.2307/3178151 Dreyfus, H.L., \& Rabinow, P. (1982). Michel Foucault: Beyond

Structuralism and Hermeneutics. 2nd ed. Chicago: University of Chicago Press.

Eisner, E. (1992). Objectivity in educational research. Curriculum inquiry, 22(1), 9-15. doi: 10.1080/03626784.1992.11075389

Fadyl, J.K., Nicholls, D.A., \& McPherson, K.M. (2013). Interrogating discourse: The application of Foucault's methodological discussion to specific inquiry. Health, 17(5), 478-494. doi:

10.1177/1363459312464073

Flick, U. (1998). An introduction to qualitative research. London: Sage Publications.

Foucault, M. (1972). The Archeology of Knowledge. London: Tavistock Publications.

Foucault, M. (1979). The History of Sexuality, Volume I: An Introduction . London: Allen Lane.

Foucault, M. (1980). Power/Knowledge: Selected Interviews and Other Writings 1972-1977. Brighton :Harvester Wheatsheaf. 
Foucault, M. (1982). The Subject and Power. Critical Inquiry 8(4), 777-795. Foucault, M. (1984). The Foucault Reader. Edited by P. Rabinow. New York: Pantheon Books.

Foucault, M. (1988a). Technologies of the Self. In L. Mart Gutman \& P. Hutton (Eds.), Technologies of the Self: A Seminar with Michel Foucault (pp. 16-49). Amherst: University of Massachusetts Press. Foucault, M. (1988b). The Care of the Self. New York: Vintage Books. Foucault, M. (1990a). The History of Sexuality. New York: Vintage Books. Foucault, M. (1990b). The Use of Pleasure. New York: Vintage Books. Foucault, M. (1991a). Politics and the Study of Discourse. In G. Burchell, C. Gordon, \& P. Miller (Eds.), The Foucault Effect (pp. 53-72). Chicago: University of Chicago Press.

Foucault, M. (1991b). Questions of Method. In G. Burchell, C. Gordon, \& P. Miller (Eds.), The Foucault Effect (pp. 73-86). Chicago: University of Chicago Press.

Glaser, B.G. (1998). Doing Grounded Theory: Issues and Discussions. Mill Valley, CA: Sociology Press.

Haber, H.F. (1996). Foucault Pumped: Body Politics and the Muscled Women. In S. Hekman (Ed.), Feminist Interpretation of Michel Foucault (pp. 137-156). Pennsylvania: The Pennsylvania State University Press.

Hanson, E.J. (1994). Issues concerning the familiarity of researchers with the research setting. Journal of Advanced Nursing, 20(5), 940-942. doi: 10.1046/j.1365-2648.1994.20050940.x

Harding, S. (1993). Rethinking standpoint epistemology: what is "strong objectivity?". In L. Alcoff \& E. Potter (Eds.), Feminist Epistemologies. London: Routledge.

Harding, S. (1991). Whose science? Whose knowledge? Thinking from women's lives. Ithaca: Cornell University Press.

Haraway, D. (1988). Situated knowledges: The science question in feminism and the privilege of partial perspective. Feminist studies, 14(3), 575599. doi: $10.2307 / 3178066$

Hicks, D. (2011). Is Longino's Conception of Objectivity Feminist? Hypatia, 26(2), 333-351. doi: 10.1111/j.1527-2001.2010.01160.x 
Hook, D. (2001). Discourse, knowledge, materiality, history: Foucault and discourse analysis. Theory \& Psychology, 11(4), 521-547. doi: $10.1177 / 0959354301114006$

Jaramillo Ruíz, F. (2013). Power, Gender and Democracy. From Domination to Gender Equality. Revista Científica General, 11(12), 107-125.

Keeley, J.F. (1990). Toward a Foucauldian Analysis of International Regimes. International Organization, 44(1), 83-1. doi:

$10.1017 / \mathrm{S} 0020818300004653$

Klein, D.B., \& Stern, C. (2009). Groupthink in academia: Majoritarian departmental politics and the professional pyramid. The Independent Review, 13(4), 585-600.

Liinason, M., \& Holm, U. (2006). PhDs, women's/gender studies and interdisciplinarity. Nordic Journal of Feminist and Gender Research, 14(2), 115-130. doi: 10.1080/08038740601084353

Longino, H. (1990). Science as social knowledge. Princeton: Princeton University Press.

Longino, H. (2002). The fate of knowledge. Princeton: Princeton University Press.

MacKinnon, C. (1982). Feminism, Marxism, Method and the State: An Agenda for Theory. Signs: Journal of Women in Culture and Society, 7(3), 515-544. doi: 10.1086/493898

McNay, L. (1991). The Foucauldian body and the exclusion of experience. Hypatia, 6(3), 125-139. doi: 10.1111/j.1527-2001.1991.tb00259.x

Metso, M., \& Le Feuvre, N. (2006). Quantitative methods for analysing gender, ethnicity and migration. Toulouse, Université de Toulouse-Le Mirail.

Merton, R. K. (1973). The normative structure of science. The sociology of science: Theoretical and empirical investigations (pp. 267-280). Chicago: University of Chicago Press.

Millman, M., \& Kanter, R.M. (Eds.) (1975). Another Voice: Feminist Perspectives on Social Life and Social Science, Garden City, NY: Anchor Doubleday.

Miles, M.B., \& Huberman, A.M. (1994). Qualitative data analysis: An expanded sourcebook. Sage. 
Nahrin, K. (2015). Objectivity and Ethics in Empirical Research. International Journal of Scientific and Research Publications, 5(7), 509- 512.

Newell, R.W. (1986). Objectivity, empiriasm, and truth. London: Routledge and Kegan Paul.

Nicholls, D.A. (2009). Putting Foucault to work: an approach to the practical application of Foucault's methodological imperatives. Aporia, 1(1), 30-40. Doi: 10.18192/aporia.v1i1.3065

O'Meara, J.T. (2001). Causation and the postmodern critique of objectivity. Anthropological Theory, 1(1), 31-56. doi:

$10.1177 / 14634990122228610$

Oakley, A. (1998a). Science, Gender, and Women's Liberation: An argument against postmodernism. Women's Studies International Forum, 21(2), 133-146. doi: 10.1016/S0277-5395(98)00005-3

Oakley, A. (1998b). Gender, Methodology and People's Way of Knowing: Some Problems with Feminism and the Paradigm Debate in Social Science. Sociology, 32(4), 707-732. doi:

$10.1177 / 0038038598032004005$

Paterson, B., \& Groening, M. (1996). Teacher-induced Countertransference in Clinical Teaching. Journal of Advanced Nursing, 23(6), 11211126. doi: 10.1046/j.1365-2648.1996.01377.x

Porter, S. (1993). Nursing Research Conventions: Objectivity or Obfuscation. Journal of Advanced Nursing, 18(1), 137-143. doi: 10.1046/j.1365-2648.1993.18010137.x

Richardson, J.T. (1996). Handbook of Qualitative Research Methods, London: BPS Books.

Richardson, L. (2000). Writing: A method of inquiry. In N.K. Denzin \& Y.S. Lincoln (Eds.), Handbook of qualitative research (2nd ed., pp 923-948). Thousand Oaks, CA: Sage.

Risman, B.J. (1993). Methodological Implications of Feminist Scholarship. The American Sociologist, Fall/Winter, 15-25

Rothstein, B. (2012). Fel av staten att stötta genusforskningen[Failure of the state to support gender research].

Rolls, L., \& Relf, M. (2006). Bracketing Interviews: Addressing Methodological Challenges in Qualitative Interviewing in 
Bereavement and Palliative Care. Mortality 11(3): 286-305. doi: 10.1080/13576270600774893

Ryff, C.D. (1895). The subjective experience of life-span transitions. In A.S. Rossi (Ed.), Gender and the Life Course (pp. 97-113). New York: Aldine Publishing Company.

Sawicki, J. (1996). Feminism, Foucault, and 'Subjects' of Power and Freedom. In S. Hekman (Ed.), Feminist Interpretation of Michel Foucault (pp. 159-178). Pennsylvania: The Pennsylvania State University Press.

Sherman, J.A., \& Beck, E.T. (Eds.) (1979). The Prism of Sex: Essays in the Sociology of Knowledge. Madison, WI: University of Wisconson Press.

Shmueli, E. (1979). How is objectivity in the social sciences possible? Journal for General Philosophy of Science, 10(1), 107-118. doi: 10.1007/BF01809030

Shenton, A.K. (2004). Strategies for ensuring trustworthiness in qualitative research projects. Education for information, 22(2), 63-75. doi:

10.3233/EFI-2004-22201

Smith, D. (1980). An examination of some socio- logical methods of thinking from the standpoint of a sociology for women, and an alternative. Unpublished manuscript prepared for the meetings of the American Sociological Association New York.

Smith, D. (1977). Some implications of a sociology for women. In N. Glazer \& H. Waehrer (Eds.), Woman in a Man-Made World: A Socioeconomic Handbook. 2nd ed. Chicago: Rand McNally.

Smith, D. (1979). A sociology for women. In J. Sherman \& E. Torton (Eds.), The Prism of Sex: Essays in the sociology of knowledge. Madison: University of Wisconsin Press.

Smith, J., \& Heshusius, L. (1986). Closing down the Conversation: The End of the Quantitative Qualitative Debate among Educational Inquirers. Educational Researcher, 15(1), 4-12. doi:

10.3102/0013189X015001004

Smith, J. (1983). Quantitative versus Qualitatitive Research: An attempt to clarify the issue. Educational Researcher, 12(3), 6-13. doi: 
Smith, J., \& Noble, H. (2014). Bias in research. Evidence-based nursing, 17(4), 100-101. doi: 10.1136/eb-2014-101946

Sociology Guide (2018). Problems of objectivity. Retrieved from Sociology

Guide website: http://www.sociologyguide.com

Söderlund, T., \& Madison, G. (2017). Objectivity and realms of explanation in academic journal articles concerning sex/gender: a comparison of Gender studies and the other social sciences. Scientometrics, 112(2), 1093-1109. doi: 10.1007/s11192-017-2407-X

Sokal, A.D. (2006). Pseudoscience and postmodernism: Antagonists of fellow-travellers? In G.G. Fagan (Ed.), Archaeological fantasies: How pseudoarchaeology misrepresents the past and misleads the public (pp. 286-361). New York, DC: Routledge.

Sprague, J., \& Zimmerman, M.K. (1989). Quality and Quantity:

Reconstructing Feminist Methodology. The American Sociologist, 20(1), 71-86. doi: 10.1007/BF02697788

Stacey, J. (1988). Can there be a feminist ethnography? Women's Studies International Forum, 11(1), 21-27. doi: 10.1016/0277-

5395(88)90004-0

Stake, R.E. (2000). The case study method in social inquiry. In R. Gomm, M. Hammersley \& P. Foster (Eds.), Case study method: Key issues, key texts. London: Sage Publications.

Stanley, L., \& Wise, S. (1993). Breaking Out Again. London: Routledge. Ström, P. (2007). Mansförtryck och kvinnovälde. Dennya välfärden[Man oppression and women's belief. The new welfare].

Thurén, B.-M. (2002). Introduction. In B.-M. Thurén (Ed.), Genusvägar: En antologi om genusforskning (pp. 5-24). Malmö: Liber.

Thurén, B.-M. (2003). Genusforskning-Frågor, villkor och utmaningar.

Stockholm: Swedish Research Council.

Tannoch-Bland, J. (1997). From aperspectival objectivity to strong objectivity: The quest for moral objectivity. Hypatia, 12(1), 155-178. doi: 10.1111/j.1527-2001.1997.tb00176.x

Tufford, L., \& Newman, P. (2012). Bracketing in qualitative research.

Qualitative social work, 11(1), 80-96. doi:

$10.1177 / 1473325010368316$ 
Wylie, A. (2004). Why standpoint matters. In S. Harding (Ed.), The feminist standpoint theory reader. London and New York: Routledge.

Weber, M. (1978). Economy and society: An outline of interpretive sociology (Vol. 1). Univ of California Press.

Westcott, M. (1990). Feminist criticism of the social sciences. In J.M.

Nielson (Eds.), Feminist Research Methods. CO: Westview Press.

Zalewski, M. (2003). Is women's studies dead? Journal of International

Women's Studies,4(2), 117-133.

Madiha Nadeem is PhD scholar in Gender Studies and Lecturer in Lahore College for Women University.

Contact Address: Department of Gender and Development Studies, Jail Road, Lahore Pakistan, +923334045609. Email: madiha.nadeem@lcwu.edu.pk 